\title{
KERUKUNAN HIDUP UMAT BERAGAMA DI DESA KEDUNGAN KECAMATAN PEDAN KABUPATEN KLATEN PROPINSI JAWA TENGAH
}

\section{Oleh : H. Abubakar Surur}

\section{PENDAHULUAN.}

Kerukunan umat beragama di Desa Kedungan adalah kerukunan yang menyeluruh, yang mencakup hubunganhubungan pribadi, hubungan sosial dan hubungan formal dalam masyarakat yang terdiri dari penganut agama Islam, Kristen, Katholik dan Hindu. Umat beragama masyarakat kedungan dalam kehidupanny a, mereka mengembangkan sikap saling menghormati dan bckcrja sama, agar tercipta kerukunan hidup diantara mereka, demi terpcliharanya kesatuan dan persatuan.

Rukun berarti bcrada dalam keadaan selaras, tenang dan tentram tanpa perselisihan dan pcrtentangan, bersatu dalam maksud untuk saling membantu (Mulder, 1978 : 39). Kerukunan secara umum berarti kedamaian dan kescpakatan. Ciri-cirinya adalah hidup berdampingan dan tidak saling menyerang, mengakui keberadaan dan hak orang lain, serta menjalin hubungan dan kerja sama.

Umat, yang dimaksud adalah masyarakat. Masyarakat adalah suatu satuan kehidupan sosial manusia yang menempati suatu wilayah tcrtentu yang keteraturan dan kehidupan sosial tersebut telah dimungkinkan karena adanya pranatapranata sosial yang telah menjadi tradisi dan kebudayaan yang dimiliki bersama (Suparlan, 1988: 83).
Agama dapat didefinisikan sebagai seperangkat aturan dan peraturan yang mengatur hubungan manusia dengan Tuhannya, mengatur hubungan manusia dengan manusia lainnya, dan mengatur hubungan manusia dengan lingkungannya (Suparlan, 1982:86).

Umat beragama dimaksudkan, masyarakat yang menganut agama yang ada. Agama merupakan sistem keyakinan yang dipunyai secara individual yang melibatkan emosi-cmosi dan pemikiran-pemiki ran yang sifatnya pribadi, yang diwujudkan dalam tindakan-tindakan keagamaan (upacara, ibadat dan amal ibadah) yang sifatnya individual atau kelompok dan sosial yang melibatkan sebagian atau scluruh masyarakat (Suparlan, 1988 : VIII).

Kajian tentang kerukunan umat beragama difokuskan pada konscp pengorganisasian identitas dan penggunaannya dalam interaksi, seperti yang dilakukan dalam pcnelitian ini, karena sctiap individu mcmpunyai identitas yang digunakan untuk bcrpcran dalam interaksi. Kcdudukan pclaku, sebagai penganut agama, selalu ada kailannya dengan kcdudukan lainnya, baik ekonomi, politik, kctetanggaan, kckerabatan, schingga muncul berbagai interaksi dalam bentuk yang yang berbeda-beda. Intcraksi-interaksi tersebut, terwujud dalam stukrut-struktur kegiatan ekonomi, formal, 
politik, tetangga, upacara-upacara keagamaan dan sosial, tolong menolong, pertemuan dan perkawinan.

Dalam kajian tentang kerukunan hidup umat beragama tidak dapat dijelaskan oleh agama, tetapi hanya dapat dijelaskan oleh atribut-atribut yang dimiliki pelakunya atau gejala-gejala lain di luar agama.

Penelitian lapangan dilaksanakan berdasarkan surat Gubernur c.q. Ketua Bappeda Tingkat I Jawa Tengah nomor R/5055/ P/VIII/91 tangp73 gal 23 Agustus 1991 dan Surat Ijin Research/Survey dari Bupati c.q. Ketua Bappeda Tingkat II Klaten nomor 072/14/111/09 tanggal 24 Agustus 1991.

Di lapangan, peneliti melakukan 3 cara. yaitu : (1) menyalin semua data di kantor Desa yang berkaitan dengan penelitian, dan membuat peta desa yang memuat potensi desa dan letak pemukiman penduduk Desa Kedungan; (2) melakukan pengamatan secara langsung mengenai pola menetap, kehidupan ekonomi, upacara-upacara, kegiatan keagamaan, dan (3) melakukan wawancara secara mendalam dengan berbagai lapisan masyarakat, tokoh-tokoh agama, pengusaha, pimpinan organisasi sosial dan politik, kepada desa dan aparat pemerintah serta pimpinan lembaga desa. Semua informasi dan data dihimpun dalam buku catatan lapangan, hasil wawancara dan pengamatan dikumpul dan ditulis dalam buku deskripsi, dan kegiatan-kegiatan yang dilaksanakan selama penelitian dicatat dalam buku kegiatan harian.

Penelitian dilakukan setelah secara resmi peneliti diterima oleh Kepala Kantor Departemen Agama Kabupaten Klaten, kemudian diantar ke KUA Kecamatan Pedan yang menemani peneliti melaporkan diri kepada Camat Pedan, kemudian diantar langsung ke lokasi yaitu Desa Kedungan. Di kantor desa peneliti diterima oleh Sekretaris Desa atau carik (Sardjono PW) kemudian diantar ke rumahnya untuk tempat menginap selama penelitian, dan hidup membaur dengan masyarakat Desa Kedungan selama 2 (dua) bulan, mulai tanggal 1 September 1991 sampai dengan tanggal 30 Oklober 1991.

Lokasi penelitian, yaitu Desa Kedungan, termasuk wilayah Kecamatan Pedan, Kabupaten Klaten, Propinsi Jawa Tengah, bcrbatas scbelah utara Desa Toroketon, timur Desa Sobayan, scbelah selatan Desa Tambakboyo, ketiganya masih dalam Kecamatan Pedan, dan sebelah barat Desa Cetan Kecamatan Ceper. Jarak antara Desa Kedungan dengan ibukota Kecamatan Pedan 300 m dan ibukota Kabupaten Klaten 14 $\mathrm{Km}$, dan Semarang, ibukota Propinsi Jawa Tengah $130 \mathrm{~km}$, dapat ditempuh dengan menggunakan bus atau mikrolet.

Keadaan tanahnya datar, luasnya 119.4350 ha atau $11,94 \mathrm{~km} 2$ terdiri dari tanah pemukiman/pekarangan 30.2630 ha, pemakaman 3.2045 ha, sawah 75.0775 ha, dan lain-lain (jalanan, lapangan, bangunan kantor dan sekolah) 10.8900 ha.

Sumber alam yang dimiliki Desa Kedungan berupa lahan pertanian yang menghasilkan padi dan palawija, tanah pekarangan menghasilkan kelapa, pisang, sayursayuran, kembang dan bahan ramuan obatobatan tradisional. Selain lahan pertanian, Desa Kedungan memiliki sumber air Umbul Tirtomoyo, Umbul Tirtomulyo dan air yang berasal dari Sungai Tegalrejo yang 
mengalir di persawahan milik penduduk, dimanfaatkan oleh petani untuk mengairi sawah mereka. Sumur, adalah sumber air yang digunakan penduduk untuk memasak, minum, mandi dan mencuci. 97\% rum ah tangga telah memiliki sumur yang digali di pekarangan mereka sendiri.

Desa Kedungan diperintah oleh seorang kepala Desa (Munawar) yang dipilih oleh rakyat dan dilantik pada tanggal 24 Agustus 1985. Desa ini terbagi menjadi 2 dusun, masing-masing Dusun I (Kadusnya Andono Budi Saputro) dan Dusun II (Kadusnya Supartono), dan dibagi menjadi 6 dukuh/ RW, masing-masing: Dukuh Kedungan/RW I, Dukuh Jalinan/RW II, Dukuh Mipitan/ RW III, Dukuh Gatak/RW IV, Dukuh Jetislor/RW V dan Dukuh Ndukuh/RW VI. Terdapat juga sejumlah 15 RT yang diketuai masing-masing Ketua RT, sedang dukuh diketahui masing-masing seorang Ketua RW.

Dalam melakanakan tugas administrasi pemerintahan, kepala desa dibantu seorang sekretaris desa atau carik (Sardjono PW) dan 2 orang kepala urusan, yaitu Kepala Urusan Pemerintahan (Prawiro Sunaryo) dan Kepala Urusan Umum (Maksum).

Untuk melaksanakan tugas pemerintahan dan memberikan pelayanan bagi masyarakat, kepala desa bersama perangkatnya berkantor di Kantor Desa Kedungan, yang dibangun dengan permanen atas swadaya masyarakat, yang terletak di pinggir jalan raya Pedan. Di kantor ini juga dipusatkan kegiatan Lembaga Musyawarah Desa (LMD) dan Lembaga Ketahanan Masyarakat Desa (LKMD). Di lokasi kantor desa dibangun juga Kantor PKK Desa Ke- dungan, bergandengan dengan kantor desa.

Penduduk Desa Kedungan seluruhnya adalah suku Jawa yang masih melaksanakan tradisi-tradisi dan kebudayaan Jawa. Jumlah penduduk 2.492 jiwa, terdiri dari jenis laki-laki 1.202 orang $(48,23 \%)$ dan wanita 1.290 orang $(51,77 \%)$. Kepadatan penduduk rata-rata $209 \mathrm{jiwa} / \mathrm{km}$, tersebar pemukimannya di 6 dukuh/RW, semuanya terdiri dari 546 KK. tiap rumah dihuni rata-rata 4 anggota keluarga. Tingkat-tingkat pendidikan penduduk adalah : Belum sekolah 612 orang, Tidak tamat SD 369 orang, Tamat SD 575 orang, Tamat SLP 418 orang, Tarn at SLA 215 orang dan Tamat Akademi dan Perguruan Tinggi 72 orang. Masyarakat yang tidak sekolah dibina melalui KejarPaket A, sehingga penduduk sudah bebas buta aksara latin. Penganut agama yang berbeda-beda di Desa Kedungan, scbelum pecahnya peristiwa G30S/ PKI, selain mereka yang menganut faham komunis, adalah beragama Islam. Tctapi setelah PKI dibubarkan, anggota-anggota komunis tersebut memilih agama Kristen atau Katholik menjadi agamanya, sehingga keberagamaan penduduk bervariasi menjadi: Umat Islam 2.404 orang $(96,47 \%)$ terdiri 528 KK. Umat Kristen 52 orang $(2,09 \%)$ sebanyak 12 KK. Umat Katholik 33 orang $(1,32 \%)$ sejumlah $5 \mathrm{KK}$, dan umat Hindu 3 orang $(0,12 \%)$ hanya 1 KK. Dalam pemukiman, umat beragama tersebut tersebar dan berbaur antara mereka dan menjadi tetangga satu dengan lainnya. Umat beragama di Desa Kedungan tidak mempunyai organisasi yang formal, kecuali umat Islam, banyak yang menganut faham Muhammadiyah, sebagai organisasi Islam satu- 
satunya yang ada di Kedungan, namun, tidak semua umat Islam masuk dalam organisasi Muhammadiyah tersebut.

\section{HASIL PENELITIAN}

Dalam kerukunan hidup umat beragama di Desa Kedungan, terdapat pola-pola hubungan di kalangan masyarakat, baik inter maupun antar umat beragama, interaksi yang menyangkut berbagai struktur kegiatan.

Dalam kegiatan ekonomi terjalin hubungan baik. Kegiatan ekonomi tidak hanya didominir oleh satu umat beragama, tetapi semua umat beragama berperan dalam kehidupan ekonomi. Perbedaan agama atau perbedaan keaktifan beragama, tidak menjadi penghalang dalam interaksi kegiatan ekonomi. Industri lurik Pak Rahmad (Katholik) mempekerjakan tcnaga manusia dari umat Katholik dan Islam. Mereka samasama bekerja dan mendapat upah yang sama.

Di pasar atau toko maupun bakulan, penjualnya banyak dari umat Islam, tetapi pembelinya bukan hanya dari umat Islam saja, tetapi dari umat Katholik, Kristen atau Hindu juga ada. Dalam hubungan ekonomi, umat beragama menunjukkan hubungan simbiotik, dan identitas agama tidak dimunculkan.

Dalam struktur formal, scperti kepala desa dan perangkatnya adalah Islam tetapi pelayanan yang diberikan kepada masyarakat diberlakukan sama. Dalam kepengurusan lembaga desa (LMD, LKMD, PKK) selain umat Islam, dari kalangan umat Katholik, dan Kristen duduk juga dalam kepengurusan dan diantara pengurus masih terdapat kerja sama dan kekompakkan. Dalam hubungan formal, tidak muncul adanya batas- batas sosial dari kalangan umat beragama.

Polilik yang diakui di Desa Kedungan adalah Golkar dan anggotanya dari seluruh lapisan masyarakat. Pegawai Negeri, aparat desa, pensiunan/purnawirawan, guru, sebagai anggota Korpri erat hubungan mereka dengan Golkar. Selain mereka, sebagian dari umat Islam cenderung menyalurkan keyakinan mereka pada PPP, sebagian pula memilih PDI bersama umat Katholik dan Kristen menjadi keyakinan politik mereka. Namun, mereka tidak menampakkan keyakinan politik yang mereka pilih, sehingga tidak pernah muncul konfiik. Umat beragama tctap membcrikan partisipasi aklif mereka dalam pembangunan scbagai salah satu tujuan politik.

Pembinaan kctcrtiban lingkungan tctap dilaksanakan olch umat beragama sclaku anggota masyarakat, sehingga kcamanan tctap tcrpelihara.

Dalam kehidupan ketetanggaan, prinsip "mong tinemong" masih dijunjung tinggi, dan masih bcrlaku sistcm "sambatan" dikalangan mereka. Tolong menolong dalam suatu pekerjaan yang membutuhkan tenaga orang lain, maka tetangga akan mclibatkan diri, diundang ataupun tidak. Pada waktu senggang, antara mereka saling mengunjungi dan bertukar pikiran. Dalam ketetanggaan berlaku hubungan kckcluargaan, semua tetangga itu dianggap keluarga sepanjang ia masih bertingkah-laku yang baik. Antara satu rumah dengan rumah lainnya, tidak dipagar, unluk mcmudahkan hubungan bila ada keperluan. Pcrsamaan atau perbedaan agama bagi merckd tidak mempengaruhi hubungan ketetanggaan tersebut. 
Setiap umat beragama mempunyai upacara-upacara keagamaan sendiri. Dalam upacara yang sifatnya ibadah, antar umat beragama tidak saling mengunjungi, tetapi mereka melakukan ibadah atau ritual keagamaan tanpa ada gangguan dari umat beragama lain, sehingga mereka melakukan ritual atau ibadah dengan tenang. Pada upacara sosial keagamaan, mereka saling bantu membantu. Pada hari raya Natal, umat Kalholik mengunjungi orang Kristen dan sebaliknya, demikian juga umat Islam mendatangi umat Katholik atau Kristen. Pada hari raya Idul Fitri, umat Islam menerima kunjungan orang Kristen atau Katholik di rumahnya untuk ziarah. Saling mengunjungi pada hari raya seperti tersebut di atas sejak lama berlaku di Desa Kedungan, dan memakan waktu paling lama 1 minggu berlangsung.

Upacara sosial yang menjadi budaya masyarakat Desa Kedungan, mempunyai nilai dalam kehidupan mereka. Umat beragama selaku anggota masyarakat, tidak terlepas dari kegiatan upacara tersebut. Ibuibu saling mengunjungi waktu ada upacara "mitonan" pada upacara kehamilan, dan pada upacara kelahiran, ibu-ibu melakukan "bayenan" atau "tilik bayi" dengan membawa uang untuk turut meringankan biaya ibu yang melahirkan. Pada upacara "selapanan" ibu-ibu datang melakukan "rewangan" untuk membantu menyiapkan kebutuhan upacara dan membawa bahan-bahan yang akan digunakan dalam selamatan, seperti beras, gula, kelapa dan buah-buahan. Kaum laki-laki memenuhi undangan pada saat selamatan. Pada waktu perkawinan, tetangga, kerabat, teman datang membantu yang laki-laki membantu mendirikan tenda di luar rumah dan kaum ibu datang membantu di dapur dan di dalam rumah. Pada hari berlangsungnya pernikahan, yang datang membantu sebelumnya, datang lagi dengan membawa uang atau kado. Pada waktu kematian, masyarakat datang melayat dengan membawa uang untuk membantu meringankan beban keluarga yang berduka. Dalam upacara menghormati leluhur, selamatan tujuh hari sampai setahun bahkan sampai pindak pisan (hari keseribu), upacaranyadihadirsemuaumat beragama. Pada tiap bulan Ruwah, umat beragama bersamasama melakukan acara sadranan di pemakaman, sepanjang dalam kuburtersebut masih ada hubungan keluarga.

Praktek tolong menolong dalam masyarakat adalah perwujudan dari salah satu budaya Jawa, yaitu "gotong royong", yang masih dijunjung tinggi dengan tidak memandang keyakinan agama atau hubungan kekerabatan atau kepentingan ekonominya. Hubungan yang dijalin dengan tolong menolong ini bukan hanya pada kegiatan yang bersifat formal, tetapi sampai pada kebutuhan rumah tanggapun masih saling membantu, sesuai ungkapan mereka "Ana sathithik didum sathithik, ana akeh didum akeh" artinya Ada sedikit dibagi sedikit, ada banyak dibagi banyak. Sifat tolong menolong yang masih kuat berakar di masyarakat, menjadikan umat beragama dapat hidup berdampingan dengan rukun.

Dalam memilih teman atau sahabat, umat beragama cenderung memilih sesama agama. Umat Islam mencari teman sesama Islam, namun, berteman dengan umat beragama yang lain agama, terjalin juga 
dengan harmonis. Perbedaan agama tidak mempengaruhi persahabatan tersebut, yang kadang-kasang terjalin karena sama-sama sekolah, atau pekerjaan yang sama.

Orangtua dalam memilih jodoh untuk anaknya, cendemng memilih yang seagama. Selama penelitian berlangsung, ada 2 (dua) pasang perkawinan menurut ajaran Islam, dan tidak dijumpai adanya perkawinan silang antara umat beragama. Tetapi sesuai data, di desa Kedungan ada 2 keluarga, suami Islam, istri Kristen dan anakpanak mereka ada yang memilih agama ayahnya (Islam) dan ada yang ikut ibunya (Kristen), tetapi kerukunan rumah tangga tetap terpelihara. Hubungan kekerabatan, keluarga masing-masing, baik dari pihak suami atau istri, tetap diakui dan terjalin dengan baik, tanpa pengaruh agama yang mereka anut masing-masing.

Pola-pola hubungan dari strukturstrukturkegiatan seperti telah dikemukakan, merupakan faktor-faktor pendukung terbinanya kerukunan umat beragama di Desa Kedungan.

Adapun faktor-faktor penghambat kerukunan, adalah masih seringnya timbul prasangka-prasangka di kalangan pemuka umat beragama terhadap agama lain, untuk mempengaruhi umat beragama yang lain masuk ke agamanya.

Pemuka-pemuka Islam yang berfaham Muhammadiyah kadang-kadang muncul stereotip-stereotip terhadap kaum santri yang mempertahan dengan tradisi leluhur dalam melakukan ibadah, yang memungkinkan adanya perbedaan-perbedaan pendapat antara mereka. Namun demikian, prasangkaprasangka dan stereotip-stereotip itu dapat diredam dengan budaya Jawa yang masih melekat bagi anggota masyarakat umat beragama di Desa Kedungan.

\section{KESIMPULAN DAN SARAN}

Masyarakat Desa Kedungan terdiri dari umat beragama dan mereka menjalankan kegiatan keagamaan menurut keyakinan agamanya. Dalam menjalankan ibadah atau ritual keagamaan, tetap dijaga ketenangan mereka dan tidak saling mengganggu, bahkan diantara umat beragama tetap dikembangkan sikap saling menghormati.

Masyarakat Desa Kedungan masih memegang tradisi dan budaya mereka, sehingga sctiap kegiatan diupacarakan, baik yang menyangkut lingkaran hidup maupun sosial keagamaan. Dalam melakukan upacara, tetangga, kerabat dan sahabat melibatkan diri untuk membantu, baik tenaga maupun dana. Dalam upacara sosial identitas agama tidak dimunculkan.

Kerukunan umat beragama di Desa Kedungan adalah kerukunan yang menyeluruh, baik antar maupun inter umat beragama, mencakup hubungan dalam semua aspek kegiatan, baik pribadi maupun kelompok masyarakat.

Pcmahaman terhadap ajaran agama, sebagian besar masih dangkal sehingga pengamalan ajaran agama dari masingmasing umat beragama belum dilaksanakan sebagaimanawajarnya. Untuk itupemimpin umat beragama perlu memberikan pemahaman kepada umat masing-masing dan membimbing melaksanakan ajaran agama, karena pengalaman ajaran agama secara baik, dapat mengkondisikan terpeliharanya kerukunan umat beragama. 
Kebudayaan Jawa yang masih dipegang oleh masyarakat Desa Kedungan dan masih mewarnai kehidupan mereka yaitu saling menghormati, ketcrbukaan dan gotongroyong, perlu dilestarikan. Sedangkan tradisi yang dapat merusak akidah agama untuk beragama dapat diluruskan, karena keyakinan agama adalah menjadi prinsip dalam kehidupan umat beragama.

\section{K E P U S T A K A A N}

Barth, Fredrik 1988 Kclompok Etnik dan Batasannya, Jakarta, Penerbit Universitas Indonesia (UI) Press, Cet. I.

Badan Litbang Agama 1989/1990 Pedoman Pcmbinaan Kerukunan Hidup Umat Beragama, Jakarta, Proyek Pembinaan Kerukunan Hidup Beragama Badan Litbang Agama, Departemen Agama.

Bratawijaya, Thomas Wiyasa 1988 Upacara Tradisional Jawa, Jakarta, Pustaka Sinar Harapan, Cet. I.

Franz M, Suseno SJ 1984 Etika Jawa, Jakarta, PT. Gramedia.
Geertz, Clifford 1989 Abangan, Santri, Priyati, Jakarta, Pustaka Jaya, Cet. Ill

Koentjaraningrat dan D.K. Emmerson 1985 Aspek Manusia dalam Penelitian Masyarakat, Jakarta, Gramedia, Cet. III.

Mulder, Niels 1986 Kepribadian Jawa dan Pembangunan Nasional, Yogyakarta, Gajah Mada University Press, VI

Suparlan, Parsudi 1981/1982 Pengetahuan Budaya, Ilmu-ilmu Sosial dan Pengkajian Masalah Masalah Agama, Jakarta, Proyek Penelitian Keagamaan Badan Litbang Agama Dep. Agama.

Syafi'i Ahmad 1990/1991 Rangkuman Penelitian Konfigurasi danTransformasi Kehidupan Agama Menjelang Tinggal Landas Pembangunan Nasional, Jakarta, Proyek Penelitian Keagamaan.

Widjaja, Drs. A.N. 1986 Manusia Indonesia : Individu, Kcluarga dan Masyarakat, Jakarta, Akadcmi Pressindo, Cet. I. 